\title{
Occurrence of actinosporean stages of myxosporeans in an inflow brook of a salmon hatchery in the Mena River System, Hokkaido, Japan
}

\author{
Csaba Székely ${ }^{1, *}$, Shigehiko Urawa ${ }^{2}$, Hiroshi Yokoyama ${ }^{3}$ \\ ${ }^{1}$ Veterinary Medical Research Institute, Hungarian Academy of Sciences, Budapest, Hungary \\ ${ }^{2}$ National Salmon Resources Center, Fisheries Agency of Japan, Sapporo, Japan \\ ${ }^{3}$ Department of Aquatic Bioscience, The University of Tokyo, Japan
}

\begin{abstract}
Actinospore infection of oligochaetes living in the mud and on the roots of vegetation in an inflow brook of a Hokkaido salmon hatchery was studied within the framework of a JapaneseHungarian research program. Two triactinomyxon types, 1 echinactinomyxon, and 1 neoactinomyxum type were isolated from the oligochaete Rhyacodrilus komarovi Timm, 1990 collected during the survey. The aurantiactinomyxons were recorded over a period of 3 mo starting from the day after oligochaete collection. The oligochaetes released actinospores for several weeks from the first day of the study. Spore excretion of individual oligochaetes was not synchronous. Of the oligochaetes examined, $0.7,7,3$ and $3 \%$, were infected with the echinactinomyxon, neoactinomyxum and the 2 types of triactinomyxon spores, respectively. Actinospore infection was intense in the positive oligochaetes in all 4 types. Of the 4 actinospore types presented here, 3 are described for the first time.
\end{abstract}

KEY WORDS: Actinosporean · Myxosporean $\cdot$ Oligochaete $\cdot$ Salmon hatchery $\cdot$ Hokkaido $\cdot$ Japan

Resale or republication not permitted without written consent of the publisher

\section{INTRODUCTION}

The first report on actinospores described these organisms (found in Bohemia) as parasites related to myxosporeans (Stolc 1899). Until quite recently this group of parasites was believed to represent an independent taxonomic entity. Research on actinosporea became more intensive after Wolf \& Markiw (1984) proved that, instead of representing a distinct taxonomic category, actinosporeans corresponded to the intraoligochaete developmental stages of fish-parasitic myxosporeans (Kent et al. 2001). The relevant research includes earlier surveys (Ormieres \& Frezil 1969), as well as studies of actinospore infection of oligochaetes in natural waters and fish farms in connection with the life cycle of myxosporeans (Hamilton \& Canning 1987 , Székely 1989, Burtle et al. 1991, Styer et al. 1992, Pote \& Waterstrat 1993, Yokoyama et al. 1993, Pallós 1995, McGeorge et al. 1997, El-Mansy et al. 1998a,b, Xiao \&

*E-mail: szekely@vmri.hu
Desser 1998a,b,c, Özer \& Wootten 2000, Székely et al. 2000, Negredo \& Mulcahy 2001). Although some actinospore types have been detected in salmon waters on Hokkaido previously (Urawa pers. comm.), their descriptions have not been published. The main objective of this work was to describe the actinospore stages of myxosporeans from a salmon biotope on Hokkaido, and thus to facilitate research on the developmental cycle of myxosporean species causing disease in salmonids. In this survey we attempted to detect the actinospore stages of myxosporean parasites of salmon in oligochaete alternate hosts in an inflow brook of a salmon hatchery of the Mena River System on the island of Hokkaido, Japan.

\section{MATERIALS AND METHODS}

The survey was conducted in an inflow brook of a salmon hatchery in the Mena River System on Hokkaido in April 2000 at the time of the melting of 
snow, at a water temperature of $4^{\circ} \mathrm{C}$. The brook and the Mena River belong to the Shiribetsu River system. The Masu salmon Onchorhynchus masou is infected by several myxosporean species, the intraoligochaete spore types of which, however, have not yet been identified. To detect these intraoligochaete actinospore types, the small oligochaetes were washed free of the mud and organic matter accumulated on the bottom of the brook with a close-meshed net, put in a small amount of brook-water in a plastic collection dish, and transported to the Sapporo Laboratory of the National Salmon Resources Center; $5 \mathrm{~h}$ after collection the oligochaetes were put individually into the wells of cell-well plates (Yokoyama et al. 1991). Before replacing the lids, the plates were covered with self-adhesive plastic foil to prevent the worms from crawling out. Starting from the subsequent day, the water layer above each oligochaete in each well was regularly examined for the presence of released actinospores. The plates were kept in refrigerator at $4^{\circ} \mathrm{C}$ throughout the study, and the water in the wells was changed once or twice a week, as needed. On the day after collection the oligochaetes were transported to the University of Tokyo, where they were examined for a further $10 \mathrm{~d}$ before transportation to Hungary, where they were monitored for actinospore release for an additional $3 \mathrm{mo}$, up to the death of the last oligochaete.

If stereomicroscopic examination indicated spore release, the actinospores floating in or adhering to the wells of the cell-well plates were examined on a slide by light microscopy at higher magnification, and microphotographs were taken of the spores using a conventional microscope photographic attachment and a digital microscope camera. Subsequently, drawings were made of the actinospores and their measurements were taken. Some of the oligochaetes observed on the cell-well plates and found to be infected were fixed in $5 \%$ glutaraldehyde, washed in sodium cacodylate solution, post-fixed in $2 \%$ osmium tetroxide, and again washed in sodium cacodylate solution. Finally the worms were embedded in Durcupan resin and cut into 0.5 to $1 \mu \mathrm{m}$ thick sections with a Reichert Jung 2040 microtome, using a glass knife. The semithin sections were stained with toluidine blue, examined in an Olympus research microscope, and digital photographs were taken of them to determine the site of spore development. The characteristic dimensions of actinospores (polar capsules, spore body, caudal processes, number of infective cells) were recorded by measuring newly released spores according to Lom et al. (1997). To determine the dimensions of actinospores, the measurements of 6 to 30 mature spores were averaged. Some of the infected oligochaetes were fixed in $80 \%$ ethanol and identified in Estonia as described by Timm (1997).

\section{RESULTS}

The several hundred oligochaete specimens collected from the inflow brook of the salmon hatchery represented species belonging to the genera Rhyacodrylus, Nais, Lumbriculus, and Enchytraeus. During the period of study, only the small, white oligochaete Rhyacodrylus komarovi Timm 1990 (Fig. 1), the most common oligochaete in the brook, was found to be infected by actinospores. The oligochaetes kept individually in the wells of the cellwell plates released actinospores as early as $24 \mathrm{~h}$ after collection. However, spore release from the individual oligochaetes was not synchronous, as some oligochaetes released mature spores only 7 to $10 \mathrm{~h}$ after collection (i.e. in Tokyo), while others did so only after further transportation (after their arrival in Hungary) over a period of 2 wk and 3 mo after collection.

\section{Description of detected actinospore types}

Of the detected actinospores, 1 proved to be a neoactinomyxum (Figs. 2 to $5 \& 22$ ), 2 were triactinomyxons (Figs. 6 to 8,9 to $11 \& 23$ to 24 ), and 1 was an echinoactinomyxon (Figs. 12 to $15 \& 25$ ). The dimensions of the individual actinospore types were determined as described by Lom et al. (1997). The most important parameters of the 4 detected actinospore types are presented in Tables 1 to 3 .

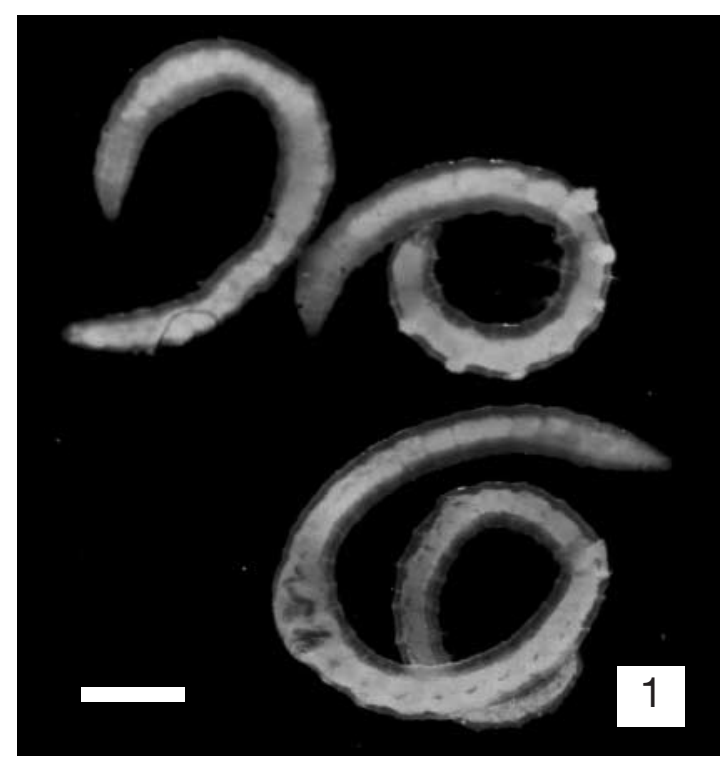

Fig. 1. Rhyacodrilus komarovi Timm 1990, a freshwater oligochaete alternate host. Scale bar $=1 \mathrm{~mm}$ 


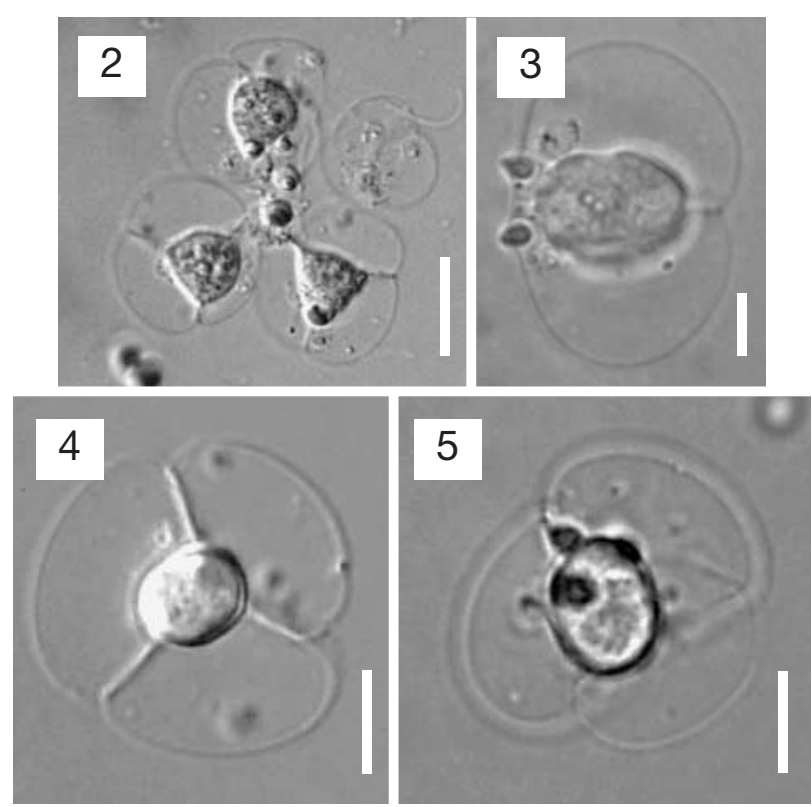

Figs. 2 to 5. Neoactinomyxum-type actinospore released from an infected Rhyacodrilus komarovi, under a coverslip. Fig. 2. Side view (scale bar $=10 \mu \mathrm{m})$. Fig. 3 . Side view (scale $\overline{\text { bar }=}$ $5 \mu \mathrm{m}$ ). Fig. 4. Apical view (scale bar $=5 \mu \mathrm{m}$ ). Fig. 5. Semiapical view (scale bar $=5 \mu \mathrm{m}$ ). Note the 3 polar capsules and the short caudal processes

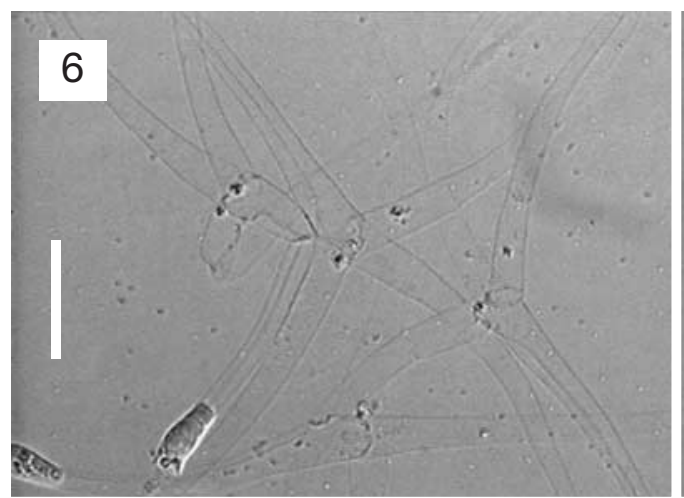

Figs. 6 to 8. Triactinomyxon Type 1 from Rhyacodrilus komarovi. Fig. 6. Floating spores under coverslip (scale bar $=50 \mu \mathrm{m}$ ). Fig. 7. Enlarged young spore body (scale bar $=5 \mu \mathrm{m}$ ). Fig. 8 . Branch of axons magnified-nucleus of valvogenic cells is clearly visible (scale bar $=5 \mu \mathrm{m}$ )

\section{Processing by semi-thin technique}

Oligochaetes releasing neoactinomyxum spores and triactinospore Type 1 on the cell-well plates were also processed by the semi-thin technique. Examination revealed the parasites in the gut epithelium of the worms or, in the case of neoactinomyxum, large masses of mature spores infesting the gut lumen. Oligochaetes found positive for actinospores were consistently extremely highly infected (Figs. 16 to 21).

\section{Differential diagnosis}

The dimensions (Tables 1 to 3) of the actinomyxon types found during the survey were compared with the types described in the literature so far:

\section{Neoactinomyxum}

The neoactinomyxum is not identical to the types described previously in the literature, although its general shape and dimensions bear great resemblance to the actinospore described as Aurantiactinomyxon eiseniellae by Ormieres \& Frezil (1969) from the oligo-
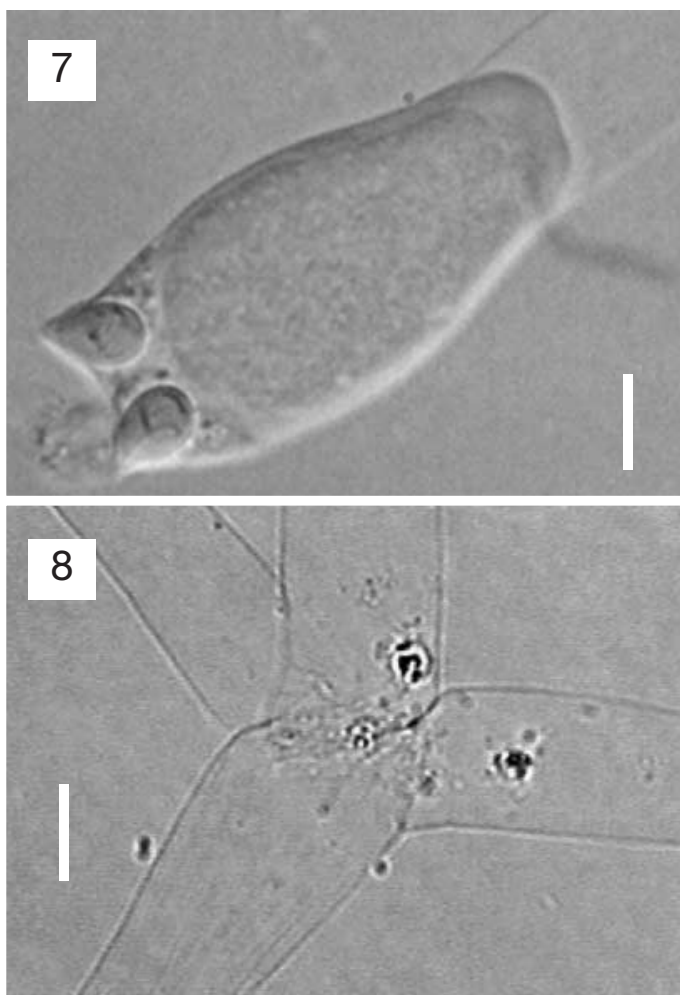

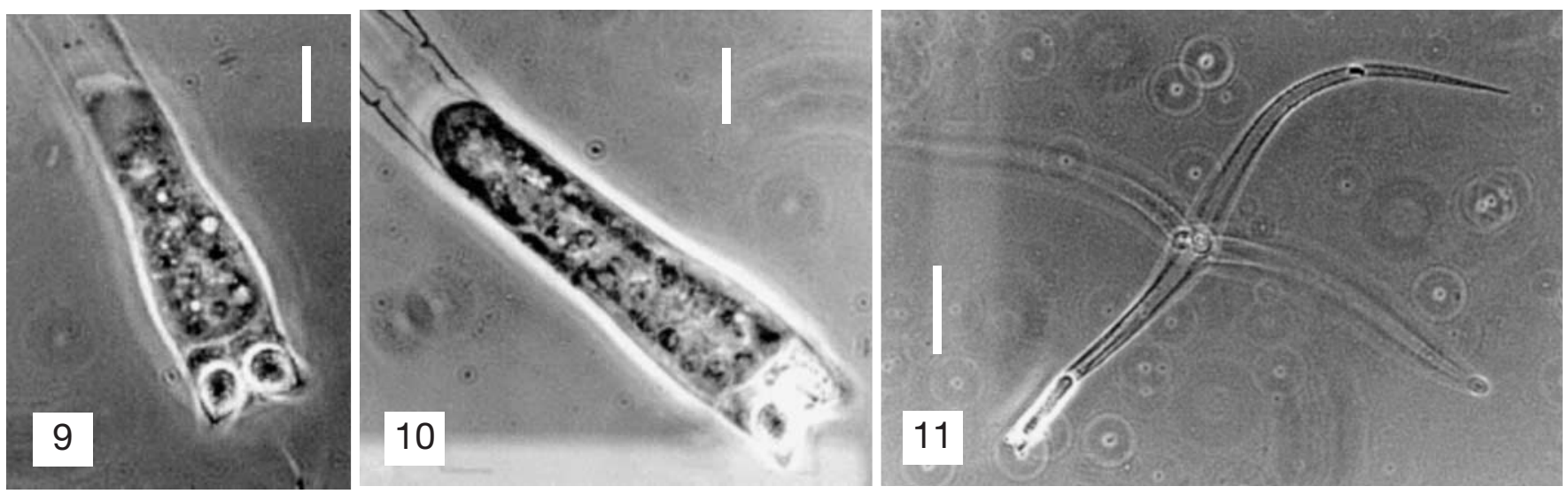

Figs. 9 to 11. Triactinomyxon Type 2 infecting Rhyacodrilus komarovi. Figs. 9 \& 10. Enlarged spore body (scale bar $=10 \mu$ m). Fig. 11. Floating triactinospore under coverslip (scale bar $=50 \mu \mathrm{m}$ )

chaete Eiseniella tetraedra (Lumbricida). However, the processes of the neoactinomyxum described in this paper are much closer together than those of the species described by Ormieres \& Frezil (1969). The neoactinomyxum type isolated by Negredo \& Mulcahy
(2001) from Lumbriculus variegatus from a river in Ireland is morphologically very similar to the type reported here; however, all dimensions of the presently described neoactinomyxum spores are much smaller, while the number of secondary cells in the
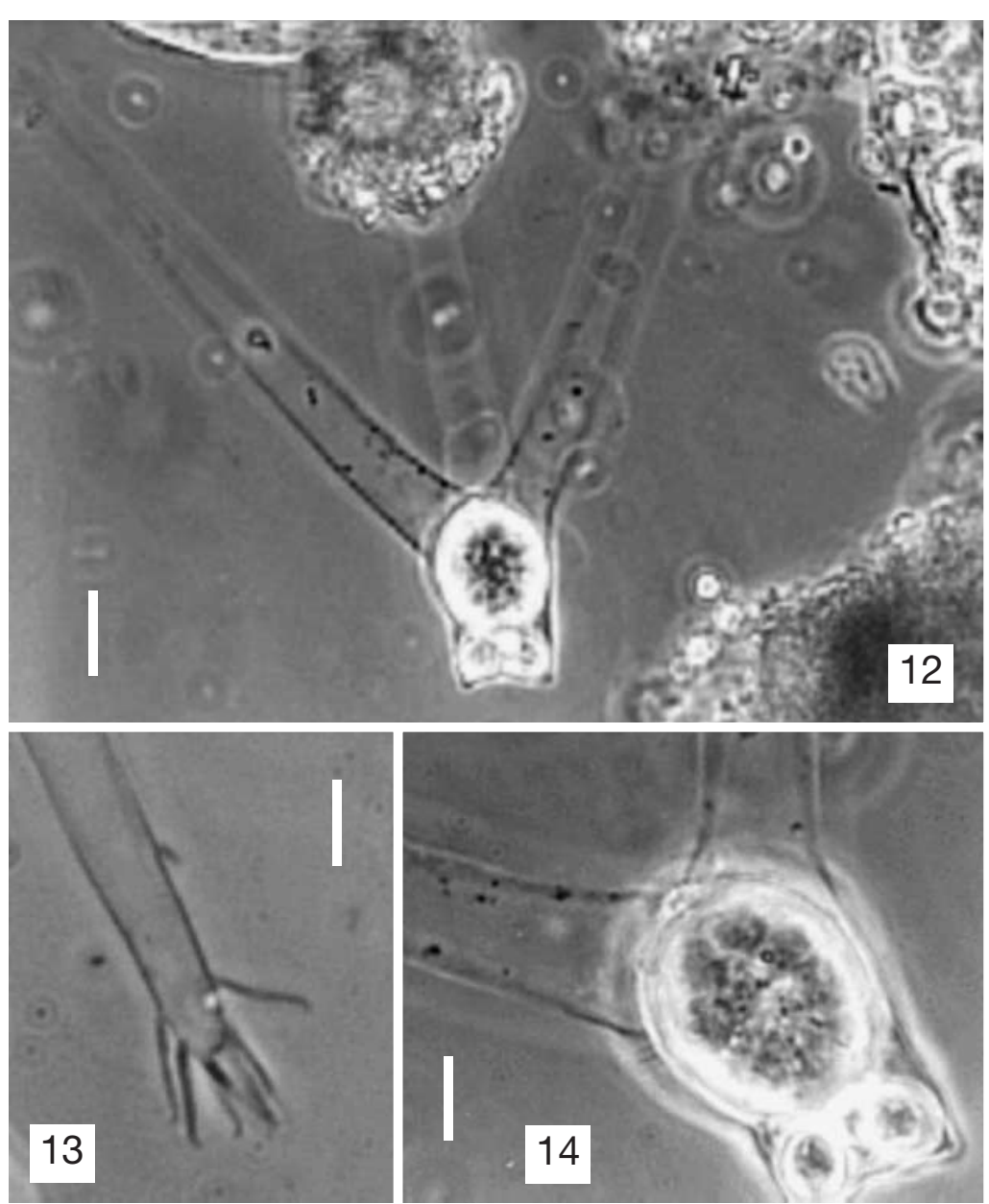

Figs. 12 to 15. Echinactinomyxon-type released from $R h y-$ acodrilus komarovi. Fig. 12. Floating spore (scale bar = $10 \mu \mathrm{m})$. Fig. 13. Enlarged furcated end of the axon (scale bar $=5 \mu \mathrm{m})$. Figs. $14 \& 15$. Enlarged spore body with 16 secondary cells (scale bar $=5 \mu \mathrm{m}$ )
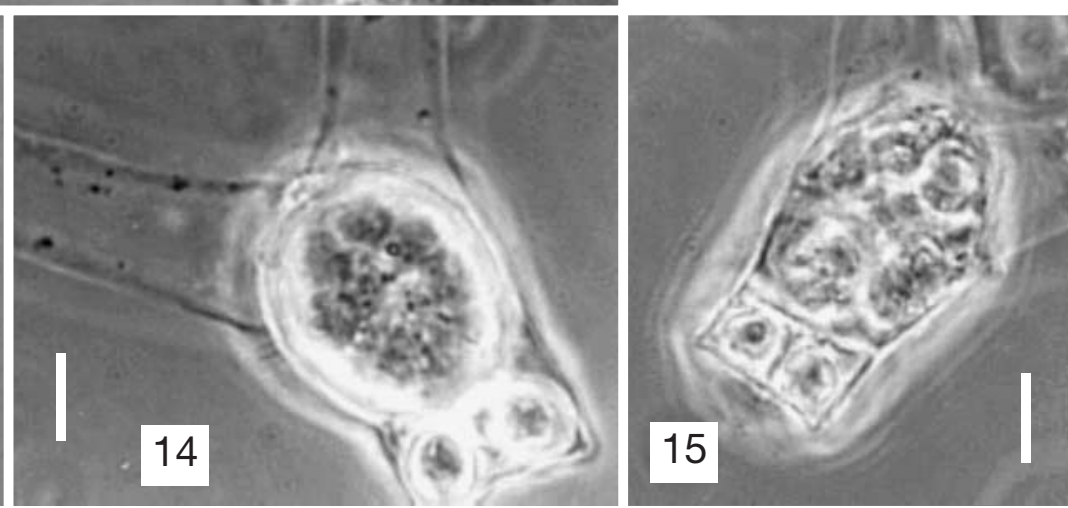
Table 1. Neoactinomyxum-type actinospore detected during the survey. Dimensions $(\mu \mathrm{m})$; values are means of 30 spores, with range in parentheses

\begin{tabular}{|lc|}
\hline Parameter & Mean (range) \\
\hline Spore body & \\
Length, side & $13.2(13.0-13.5)$ \\
Width, apical & $11.5(10.8-12.1)$ \\
Caudal process & \\
Length, apical & $10.8(9.2-11.0)$ \\
Width, apical & $21.1(19.2-23)$ \\
Polar capsule & \\
Length, side & $2.1(2.8-3.0)$ \\
Width, side & $2.9(2.0-2.2)$ \\
No. sporoplasm & 32 \\
cells (approx.) & \\
\hline
\end{tabular}

sporoplasm is double that in the Irish isolate. The neoactinomyxum detected in this work greatly differs in shape (and size) from all other neoactinomyxum types described in the literature (Janiszewska 1955, Yokoyama et al. 1993, El-Mansy et al. 1998a).

\section{Triactinomyxon Types 1 and 2}

The smaller of the 2 detected triactinospores (Type 1) is not identical with any of the triactinomyxon types described in the literature so far, differing either in its dimensions or in the number of secondary cells located in the sporoplasm (Janiszewska 1957, El-Matbouli \& Hoffmann 1989, 1993, 1998, Kent et al. 1993, Urawa 1994, El-Mansy \& Molnár 1997a,b, El-Mansy et al. 1998a,b,c, Xiao \& Desser 1998a, Székely et al. 1999,

Table 2. Triactinomyxon Types 1 and 2. Measurements $(\mu \mathrm{m})$; values are means of 20 triactinospores, with range in parentheses

\begin{tabular}{|lcc|}
\hline Parameter & Type 1 & Type 2 \\
\hline $\begin{array}{l}\text { Polar capsules } \\
\text { Length }\end{array}$ & $6.0(5.5-6.2)$ & $5.6(5-5.9)$ \\
$\quad$ Width & $3.5(3.2-3.8)$ & $3.7(3.5-4.2)$ \\
No. infective & & \\
$\quad$ cells (approx.) & 32 & 64 \\
Sporoplasm & & \\
$\quad$ Length & $35(28.9-30.8)$ & $62(57.5-75)$ \\
$\quad$ Width & $12.5(10-14)$ & $9.1(8.75-12.2)$ \\
Style & $125(112-150)$ & $138(122-142)$ \\
Length & $10(7-14)$ & $13.8(13-14.2)$ \\
Caudal processes & $178(162-200)$ & $187(175-205)$ \\
$\quad$ Width & $354(330-390)$ & $375(350-401)$ \\
Length & & \\
Largest span & & \\
\hline
\end{tabular}

Table 3. Echinactinomyxon actinospore. Measurements $(\mu \mathrm{m})$; values are means of 6 spores, with range in parentheses

\begin{tabular}{|lc|}
\hline Parameter & Mean (range) \\
\hline Polar capsules & \\
Length & $6(5-7)$ \\
Width & $4.4(4-5)$ \\
Sporoplasm & \\
Length & $24.3(21.1-27.5)$ \\
Width & $18.5(17.6-20.2)$ \\
No. infective cells (approx.) & 16 \\
Caudal processes (furcated portion) & \\
Length & $7.8(5.8-9.6)$ \\
Caudal processes & \\
Length & $99.1(87.5-109.8)$ \\
Width (at the base) & $8.9(8.2-10.3)$ \\
\hline
\end{tabular}

Eszterbauer et al. 2000). The larger spore (Type 2) also differs from the triactinomyxon types described by the above-cited authors, but shows similarity, both in its dimensions and in the number of secondary cells in the sporoplasm ( $>60$ ), to the triactinomyxon type isolated by McGeorge et al. (1997) from an unidentified oligochaete collected from a salmon hatchery in Scotland.

\section{Echinactinomyxon}

Unlike echinactinomyxons described in the literature so far, which all have a non-branched style (Janiszewska 1957, Xiao \& Desser 1998a,b, Özer \& Wootten 2000), the axon ends of the echinactinomyxon spore detected in this study are furcated. The new type of echinactinomyxon shows similarity only with the actinospore described by Janiszewska \& Krzton (1973) as Raabeia furciligera and with the Myxobolus dispar actinospore obtained experimentally by Molnár et al. (1999); both of these have furcated axon ends. The echinactinomyxon reported in this paper differs from the latter actinospores in several morphological features, however; e.g. it has 16 secondary cells in its sporoplasm, while the other 2 types have 24 and 32 secondary cells, respectively.

\section{DISCUSSION}

While Ikeda (1912), Mackinnon \& Adam (1924), Janiszewska $(1955,1957)$ and Ormieres \& Frezil (1969) regarded actinospores exclusively as parasites of oligochaetes, the natural-water surveys conducted after the pioneering work of Wolf \& Markiw (1984) recorded these parasites as actinospore forms of fishparasitic myxosporeans, developing in oligochaetes as 

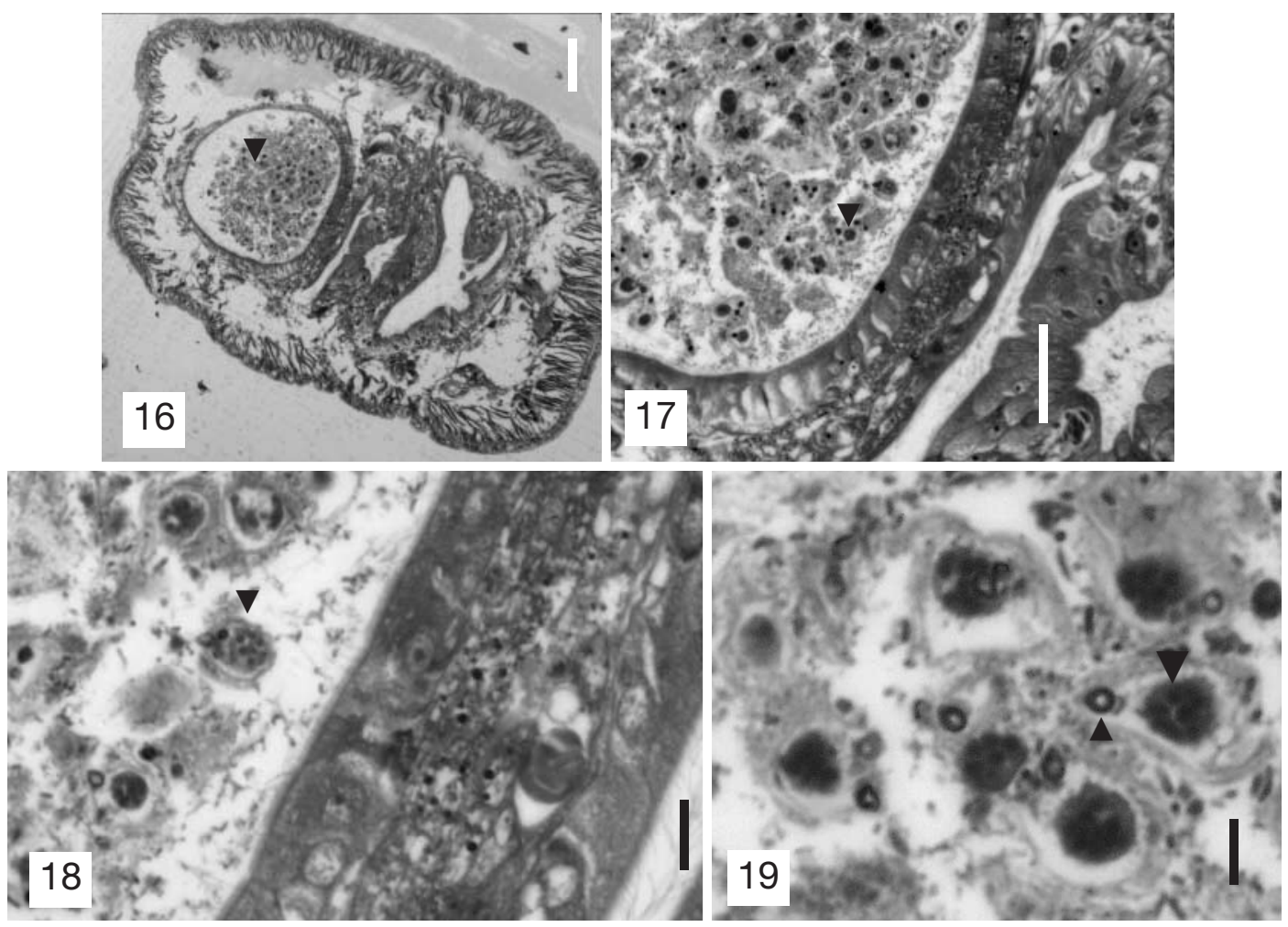

Figs. 16 to 19. Neoactinomyxum-infected Rhyacodrilus komarovi oligochaete: semi-thin sections stained with toluidine blue. Fig. 16. Low-magnification (scale bar $=200 \mu \mathrm{m}$ ) of a cross-section of the infected worm, numerous neoactinospores can be seen in the gut-lumen (arrowhead). Fig. 17 (scale bar $=100 \mu \mathrm{m}) \&$ Fig. 18 (scale bar $=20 \mu \mathrm{m}$ ). Intestinal epithelium of the worm infected with mature pansporocysts, but the majority of the spores are released into the gut lumen (arrowheads). Fig. 19. Enlarged spores from the gut-lumen (scale bar $=10 \mu \mathrm{m}$ ), secondary cells (large arrowhead) of the spores, and polar capsule (small arrowhead)

alternate hosts (Hamilton \& Canning 1987, Székely 1989, Burtle et al. 1991, Styer et al. 1992, Pote \& Waterstrat 1993, Yokoyama et al. 1993, Koller 1994, Pallós 1995, McGeorge et al. 1997, El-Mansy et al. 1998a,b, Xiao \& Desser 1998a,b,c, Negredo \& Mulcahy 2001). Most authors reported relatively low $(<1 \%)$ prevalence of infection, and only Yokoyama et al. (1993), El-Mansy et al. (1998a,b) and Negredo \& Mulcahy (2001) detected infections of a prevalence much higher than that in oligochaetes in natural waters. However, the method used by the later authors substantially differed from that used in the earlier studies; namely, while the earlier authors determined the infection of an oligochaete specimen at a given moment in time, El-Mansy et al. (1998a,b), Székely et al. (2000), Negredo \& Mulcahy (2001), and the present authors monitored the infection status of individual oligochaetes on cell-well plates by daily checks over a long period of time. This possibly explains the much higher prevalence values in the later studies. However, with low-level infection
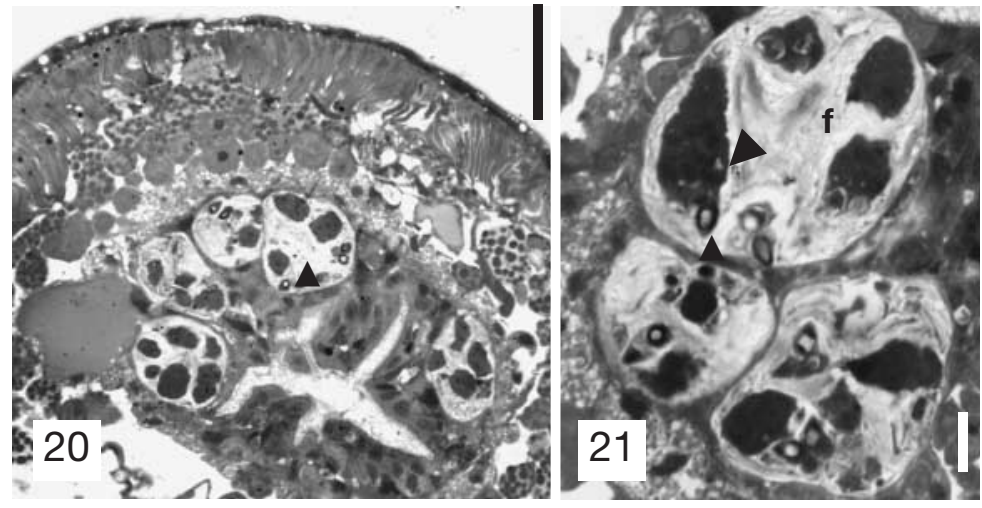

Figs. 20 \& 21. Triactinomyxon Type 1-infected Rhyacodrilus komarovi; semi-thin section (stained with toluidine blue). Fig. 20. Heavy infection of the gut epithelium with pansporocysts (scale bar = $50 \mu \mathrm{m}$ ). Fig. 21. Enlarged pansporocysts (scale bar = $10 \mu \mathrm{m})$; the polar capsules (small arrowhead), the infectious cells (large arrowhead) and the folded axons (f) are well differentiated 


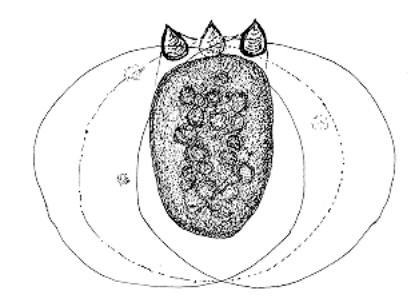

22
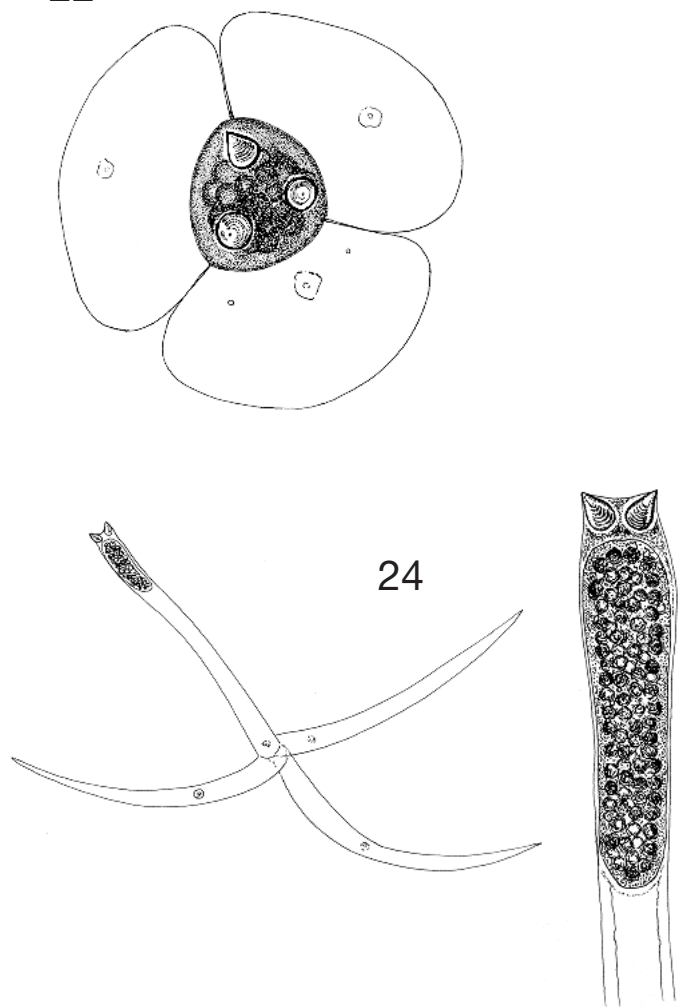

in the biotope, even long-term surveys would reveal a low prevalence of actinospore infection of oligochaetes (Xiao \& Desser 1998a,b,c).

Based upon the features described in the subsection 'Differential diagnosis', 3 of the 4 actinospore types detected in this study appear to be new forms hitherto not described in the literature. However, triactinomyxon Type 2 is likely to be identical with the type detected by McGeorge et al. (1997) in an oligochaete collected from the sediment of a salmon hatchery.

The possible relationship of these actinospore forms to other myxosporean species needs to be estimated by infection experiments or by the use of molecular biological techniques.

Acknowledgements. The authors wish to thank the JSPSHungarian Academy Agreement (No. 26) and the Hungarian Scientific Research Fund (OTKA) Contracts Nos. T 031755 and 029200, which allowed us to work on this project. We thank Dr. Tarmo Timm for identification of the oligochaetes and Zsuzsa Kis for preparing the semi-thin sections.
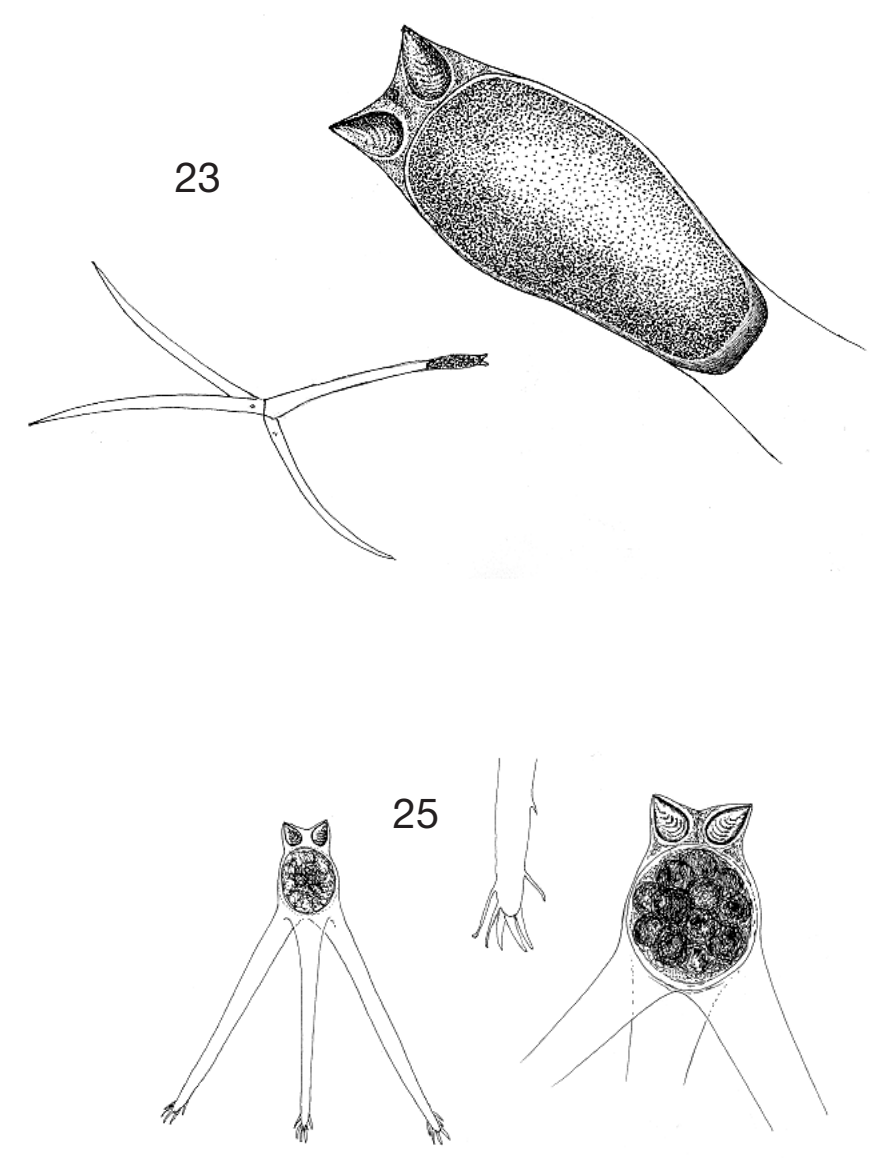

Figs. 22 to 25. Schematic drawings of the actinospores. Fig. 22. Neoactinomyxum. Fig. 23. Triactinomyxon Type 1. Fig. 24. Triactinomyxon Type 2. Fig. 25. Echinactinomyxon

\section{LITERATURE CITED}

Burtle GJ, Harrison LR, Styer EL (1991) Detection of a triactinomyxid myxozoan in an oligochaete from ponds with proliferative gill disease in channel catfish. J Aquat Anim Health 3:281-287

El-Mansy A, Molnár K (1997a) Extrapiscine development of Myxobolus drjagini Akhmerow, 1954 (Myxosporea: Myxobolidae) in oligochaete alternative hosts. Acta Vet Hung 45:427-438

El-Mansy A, Molnár K (1997b) Development of Myxobolus hungaricus (Myxosporea: Myxobolidae) in oligochaete alternate hosts. Dis Aquat Org 31:227-232

El-Mansy A, Székely Cs, Molnár K (1998a) Studies on the occurrence of actinosporean stages of fish myxosporeans in a fish farm of Hungary, with the description of triactinomyxon, raabeia, aurantiactinomyxon and neoactinomyxon types. Acta Vet Hung 46:259-284

El-Mansy A, Székely Cs, Molnár K (1998b) Studies on the occurrence of actinosporean stages of myxosporeans in Lake Balaton, Hungary, with the description of triactinomyxon, raabeia and aurantiactinomyxon types. Acta Vet Hung 46:437-450

El-Mansy A, Molnár K, Székely Cs (1998c) Development of Myxobolus portucalensis (Myxosporea: Myxobolidae) in 
the oligochaete Tubifex tubifex (Müller). Syst Parasitol 41: 95-103

El-Matbouli M, Hoffmann RW (1989) Experimental transmission of two Myxobolus spp. developing bisporogeny via tubificid worms. Parasitol Res 75:461-464

El-Matbouli M, Hoffmann RW (1993) Myxobolus carassii Klokaceva, 1914 also requires an aquatic oligochaete, Tubifex tubifex as an intermediate host in its life cycle. Bull Eur Assoc Fish Pathol 13: 189-192

El-Matbouli M, Hoffmann RW (1998) Light and electron microscopic study on the chronological development of Myxobolus cerebralis in Tubifex tubifex to the actinosporean stage triactinomyxon. Int J Parasitol 28:195-217

Eszterbauer E, Székely Cs, Molnár K, Baska F (2000) Development of Myxobolus bramae (Myxosporea: Myxobolidae) in an oligochaete alternate host, Tubifex tubifex. J Fish Dis 23:19-25

Hamilton AJ, Canning EU (1987) Studies on the proposed role of Tubifex tubifex (Muller) as an intermediate host in the life cycle of Myxosoma cerebralis (Hofer, 1903). J Fish Dis 10:145-151

Ikeda J (1912) Studies on some sporozoan parasites of sipunculoids. I. The life history of a new actinomyxidian, Tetractynomyxon intermedium g. et sp. nov. Arch Protistenkd 25:240-242

Janiszewska J (1955) Actinomyxidia: morphology, ecology, history of investigations, systematics, development. Acta Parasitol Pol 2:405-443

Janiszewska J (1957) Actinomyxidia. II. New systematics, sexual cycle, description of new genera and species. Zool Pol 8:3-34

Janiszewska J, Krzton M (1973) Raabeia furciligera sp.n. (Cnidosporidia, Actinomyxidia) from the body cavity of Limnodrilus hoffmeisteri Claparede, 1862. Acta Protozool 12:165-167

Kent ML, Whitaker DJ, Margolis L (1993) Transmission of Myxobolus arcticus Pugachev and Khokhlov, 1979, a myxosporean parasite of Pacific salmon, via a triactinomyxon from the aquatic oligochaete Stylodrilus heringianus (Lumbriculidae). Can J Zool 71:1207-1211

Kent ML, Andree KB, Bartholomew JL, El-Matbouli M and 12 others (2001) Recent advances in our knowledge of the myxozoa. J Eukaryot Microbiol 48:395-413

Köller E (1994) Verbreitung von Actinosporea in zwei Salmoniden-Teichwirtschaften. Dipl.-Arb., Universität München

Lom J, McGeorge J, Feist SW, Morris D, Adams A (1997) Guidelines for the uniform characterisation of the actinosporean stages of parasites of the phylum Myxozoa. Dis Aquat Org 30:1-9

Mackinnon DL, Adam DI (1924) Notes on sporozoa parasitic in Tubifex. I. the life history of triactinomyxon. Q J Microsc Sci 68:187-209

McGeorge J, Sommerville C, Wootten R (1997) Studies of actinosporean myxozoan stages parasitic in oligochaetes from sediments of a hatchery where Atlantic salmon harbour Sphaerospora truttae infection. Dis Aquat Org 30: 107-119

Molnár K, El-Mansy A, Székely Cs, Baska F (1999) Development of Myxobolus dispar Thelohan, 1895 (Myxosporea: Myxobolidae) in an oligochaete alternate host Tubifex tubifex (Müller). Folia Parasitol (Geske Budejovice) 46: $15-21$

Negredo C, Mulcahy MF (2001) Actinosporean infection in the oligochaetes in a river system in southwest Ireland with descriptions of three new forms. Dis Aquat Org $46: 67-77$

Editorial responsibility: Wolfgang Körting,

Hannover, Germany
Ormieres R, Frezil JL (1969) Aurantiactinomyxon eiseniellae n. sp., Actinomyxidie Parasite d'Eiseniella tetraedra Sav. (Oligochaeta - Lumbricidae). Protistologica 5:137-144

Özer A, Wootten R (2000) The life cycle of Sphaerospora truttae (Myxozoa: Myxosporea) and some features of the biology of both the actinosporean and myxosporean stages. Dis Aquat Org 40:33-39

Pallós A (1995) Occurrence of actinosporean stages of myxosporeans in oligochaetes. MSc thesis. University of Veterinary Sciences, Budapest (in Hungarian)

Pote LM, Waterstrat P (1993) Motile stage of Aurantiactinomyxon sp. (Actinosporea: Triactinomyxidae) isolated from Dero digitata found in channel catfish ponds during outbreaks of proliferative gill disease. J Aquat Anim Health $5: 213-218$

Stolc A (1899) Actinomyxidies, nouveau groupe de Mesozoaires parent des Myxosporidies. Bull Int Acad Sci Boheme 22:1-12

Styer EL, Harrison LR, Burtle GJ (1992) Six new species of Actinomyxids from Dero digitata. Abstracts of Papers. In: Lom J, Körting W (eds) International Workshop on Myxosporea, České Budějovice. October 6-8, 1992. Institute of Parasitology, České Budějovice, p 5

Székely Cs (1989) Fish parasitic myxosporeans and a new method to control them. Doctoral dissertation, Agricultural University of Gödöllõ (in Hungarian)

Székely Cs, Molnár K, Eszterbauer E, Baska F (1999) Experimental detection of the actinospores of Myxobolus pseudodispar (Myxosporea: Myobolidae) in oligochaete alternate hosts. Dis Aquat Org 38:219-224

Székely Cs, Sitja-Bobadilla A, Alvarez-Pellitero P (2000) First report on the occurrence of an actinosporean stage (Myxozoa) in oligochaetes from Spanish freshwaters. Acta Vet Hung 48:433-441

Timm T (1997) Freshwater Oligochaeta of some urban watercourses in the Russian Far East. Int Rev Gesamten Hydrobiol 82:437-467

Urawa S (1994) Life cycle of Myxobolus arcticus, a myxosporean parasite of salmonid fishes. Book of abstracts. In: Hedrick RP, Winton JR (eds) International Symposium on Aquatic Animal Health. Seattle, 4-8 September 1994. (ref P-W-10.3), Washington

Wolf K, Markiw M E (1984) Biology contravenes taxonomy in the Myxozoa: new discoveries show alternation of invertebrate and vertebrate hosts. Science 225:1449-1452

Xiao C, Desser SS (1998a) Actinosporean stages of myxosporean parasites of oligochaetes from Lake Sasajewun, Algonquin Park, Ontario: new forms of triactinomyxon and raabeia. J Parasitol 84:998-1009

Xiao C, Desser SS (1998b) Actinosporean stages of myxozoan parasites of oligochaetes from Lake Sasajewun, Algonquin Park, Ontario: new forms of echinactinomyxon, neoactinomyxum, aurantiactinomyxon, guyenotia, synactinomyxon and antonactinomyxon. J Parasitol 84:1010-1019

Xiao C, Desser SS (1998c) The oligochaetes and their actinosporean parasites in Lake Sasajewun, Algonquin Park, Ontario. J Parasitol 84:1020-1026

Yokoyama H, Ogawa K, Wakabayashi H (1991) A new collection method of actinosporeans - a probable infective stage of myxosporeans to fishes-from tubificids and experimental infection of goldfish with the actinosporean, Raabeia sp. Fish Pathol (Gyobio Kenkyu) 26:133-138

Yokoyama H, Ogawa K, Wakabayashi H (1993) Involvement of Branchiura sowerbyi (Oligochaeta: Annelida) in the transmission of Hoferellus carassii (Myxosporea: Myxozoa), the causative agent of kidney enlargement disease (KED) of goldfish Carassius auratus. Fish Pathol 28:135-139

Submitted: April 2, 2001; Accepted: October 7, 2001

Proofs received from author(s): April 19, 2002 